\title{
Using the Theory of Planned Behaviour to understand binge drinking: the importance of beliefs for developing interventions
}

David P. French ${ }^{1}$, and Richard Cooke ${ }^{2}$

1. Applied Research Centre in Health and Lifestyles Interventions, Coventry University

2. Psychology, School of Life Sciences, Aston University

*Corresponding author;

Professor David P. French

Applied Research Centre in Health and Lifestyles Interventions,

Faculty of Health and Life Sciences,

Coventry University,

Whitefriars Building,

Priory Street,

Coventry

CV1 5FB

Tel: $+44(0) 2476885429$

Fax: +44(0)2476 795987

Email: david.french@coventry.ac.uk

Running title: Beliefs about binge drinking

Key words: binge drinking; theory of planned behaviour; outcome expectancies; alcohol; beliefs 


\section{Using the Theory of Planned Behaviour to understand binge drinking: the importance of beliefs for developing interventions}

\section{Objectives}

To elicit students' salient beliefs in relation to binge drinking, and to examine the extent to which individual salient beliefs predict Theory of Planned Behaviour (TPB) constructs in relation to binge drink, and actual drinking behaviour assessed later that evening.

\section{Design}

Longitudinal, over a single evening

\section{Methods}

192 students were recruited as they entered a campus bar at the beginning of the evening. They completed questionnaires with open-ended questions eliciting beliefs concerning binge drinking, and ratings scales assessing standard TPB constructs in relation to binge drinking. At the end of the evening, 181 completed a second questionnaire and recorded the number of alcoholic drinks they had consumed.

\section{Results}

Beliefs were reliably coded (all kappas $\geq 0.79$ ). Students with higher intentions to binge drink were more likely to believe that their friends approved of binge drinking, and that (lack of) money would make it difficult. Students who reported drinking more alcohol at the end of the evening were more likely to believe that getting drunk is an advantage/ what they would like about binge drinking tonight, that their sports teams would approve, and that celebrating, drinking patterns, and environment would make it easy to binge drink.

\section{Conclusions}

The present study has identified the individually salient beliefs relating to drinking behaviour that the TPB states should be addressed by interventions to alter behaviour, and which that should be assessed as mediators in intervention research. As a whole, these findings highlight the importance of perceived peer norms in binge drinking in this population, and support the idea of interventions to challenge the perception of social pressure to binge drink. 


\section{Introduction}

Alcohol consumption is one of the leading causes of preventable mortality in Western societies (Mokdad et al., 2004), and is associated with violence, traffic accidents, other injuries, chronic diseases and social problems (Babor et al., 2003). National surveys in Great Britain (e.g. Lader \& Steel, 2010) have repeatedly shown a high prevalence of excessive alcohol consumption among young people. For instance, among those aged $16-24$ years, $33 \%$ of men reported drinking more than 8 units, and $19 \%$ of women reported drinking more than 6 units, on at least one day in the past week. This number of units of alcohol is double the amount defined as "sensible" daily consumption by the Department of Health for England (1995). The dangers of such patterns of alcohol consumption include risk of alcohol poisoning, accidents and injuries in the short-term, and if maintained, increased likelihood of premature mortality, chronic health conditions such as cancers, stroke, liver cirrhosis, and brain damage of various kinds, as well as social problems relating to employment and crime (Babor et al., 2003).

Given this, it is important to understand the psychological determinants of binge drinking in young people. One theory which has been used to understand healthrelated behaviour in hundreds of studies (Conner \& Sparks, 2005) is the Theory of Planned Behaviour (TPB; Ajzen, 1991). According to this theory, behaviour is predicted by intention to perform that behaviour and perceived behavioural control. The TPB further proposes that intentions are influenced by a person`s evaluation of the behaviour (attitude), their perception of the social pressure to engage in that behaviour (subjective norm) and their perception of their ability to carry out that behaviour (perceived behavioural control), and that these constructs are in turn underpinned by beliefs. Attitudes towards the behaviour are proposed to arise from a combination of beliefs about its consequences (behavioural beliefs) and evaluations of those consequences (outcome evaluations). Subjective norms are based on perceptions of the views about the behaviour of other individuals or groups (normative beliefs) and the strength of the individual's desire to gain approval of these groups (motivation to comply). PBC is underpinned by a set of beliefs which refer to the perceived presence of factors that may influence or impede performance of a behaviour (control beliefs) and the perceived impact that facilitating or inhibiting factors may have on performance of behaviour (power of control beliefs). 
The TPB has been applied numerous times to understand drinking intentions and behaviour in young people (e.g. Norman et al., 1998; Conner et al., 1999; Armitage et al., 2002; Johnston \& White, 2003; Cooke et al, 2007; Norman et al., 2007). Despite different definitions and measures of drinking included in these studies, it is clear that the TPB is a good predictor of a variety of measures of drinking behaviour for student populations. There is consistent evidence that attitudes, and subjective norms predict intentions and that intentions predict behaviour. By contrast, the pattern of findings relating to PBC is more mixed (Norman \& Conner, 2006). In some studies, PBC is negatively associated to frequency of binge drinking (Armitage et al., 1999; Norman et al., 1998; Norman \& Conner, 2006), with those high in control engaging in more binge drinking, but positively associated to binge drinking in others (e.g. Johnston \& White, 2003; McMillan \& Conner, 2003).

One limitation with the majority of these studies is that few of these studies using the TPB to understand student binge drinking behaviour have examined beliefs about drinking alcohol. This is unfortunate, given that according to Ajzen (1991), beliefs are the ultimate psychological determinants of behaviour. That is, to bring about change in behaviour, or at least intentions to perform a behaviour, one needs to alter those beliefs (Ajzen, 2007). Thus, to design interventions to alter intentions to binge drink in students, one needs to know not only what are the salient beliefs regarding this behaviour in this population, but also which beliefs are associated with intentions and behaviour (Sutton, 2002; Sutton, 2010).

The TPB studies that have assessed beliefs to date have done so using rating scales assessing all the beliefs that are salient to the population of interest, i.e. modally salient beliefs (Norman et al., 1998; Murgraff et al., 2001). The drawback with this approach is that according to the theory, behaviour is determined by individually salient beliefs, i.e. those which come to mind when participants are asked open-ended questions about a behaviour (see Sutton et al., 2003). It has been demonstrated repeatedly since the study of Kaplan and Fishbein (1969) that it is individually salient beliefs which are more predictive of an individual's subsequent attitudes, intentions, and behaviour, rather than beliefs which are modally salient for the population, but not for the individual (see also Agnew, 1998; Steadman et al., 2002). 
Rating scales do not distinguish between those beliefs which are salient for the individual and those which are not. By contrast, the present study elicited individuals' beliefs about binge drinking by asking questions about e.g. the advantages of binge drinking, thereby ensuring that only salient beliefs were elicited.

The current study is longitudinal over the course of a single evening. Participants were asked about their beliefs about binge drinking on that particular evening rather than in general and at the end of that evening were asked again about their behaviour. Thus, in contrast to most previous research in this area, the study examined the predictors of intentions and behaviour on a single occasion. The issue concerning which is the best timescale over which to examine binge drinking behaviour is one which the TPB has little to say, beyond that the timescale should be identical in all measures employed, i.e. the TACT principle (Ajzen \& Fishbein, 1977). Given that the majority of students binge drink on a weekly basis (e.g. Norman \& Conner, 2006), it may be more profitable to understand the different beliefs that underlie binge drinking on individual occasions, rather than the beliefs which distinguish between those who binge drink more or less frequently. This is, however, an empirical question, and one to which the present research contributes. Cooke et al. (2007) pointed out the need to carry out research in applied settings and this study took place in a bar to improve ecological validity. Thus, the present study looked at the beliefs of students in the environment in which the behaviour of interest occurred, as these are the beliefs that interventions to reduce drinking in bars would aim to address.

The present study had three main aims:

1. To identify individually salient beliefs in relation to binge drinking for a student sample

2. To look at the extent to which individual salient beliefs predict the TPB constructs that they are determinants of, according to the theory (namely one of Attitudes, Subjective Norm, or PBC), intention to binge drink and actual drinking behaviour over the course of that evening

3. To look at the extent to which structured TPB measures predict intention to binge drink and actual drinking behaviour over the course of that evening 


\section{Methods}

\section{Participants}

Students attending the student union bar at the University of Birmingham, UK over the course of several weekday evenings were recruited to participate in the study. Of the 221 students who were approached, 192 took part, giving a response rate of $87 \%$ for those answering the first questionnaire. These were 96 males and 96 females. The mean number of units drank by the students in a typical week was 25 . Of the 192 students, 181 students were willing to answer the second questionnaire.

\section{$\underline{\text { Design }}$}

This was a longitudinal study carried out over the course of an evening.

\section{$\underline{\text { Procedure }}$}

The research had ethical approval from the University of Birmingham. Potential participants were approached in the student union at the beginning of the evening and asked to complete two questionnaires, one immediately and one at the end of the evening. Those who had already been drinking were not invited to participate, nor were those who had participated on a previous evening. Participants were given written and verbal information regarding the study and those who agreed to take part completed a consent form.

\section{$\underline{\text { Measures }}$}

Participants were provided with a definition of binge drinking: consuming more than 10.5 units for men and 7 units for women in a single session. The definition used in the present study was based on the guidelines applicable in the United Kingdom prior to 1995 (Department of Health, 1995), of "sensible" drinking in terms of weekly intakes, i.e. 21 units for men and 14 units for women, where a unit is equivalent to 10 $\mathrm{ml}$ of pure ethanol. A variety of definitions of binge drinking have been used in the TPB literature (Gill 2002; Murgraff et al., 1999). Defining binge drinking as the consumption of half of these weekly units in a single session was used to promote comparability with previous research (e.g. Norman et al., 1998; Cooke et al., 2007).

Participants were then shown a list of common alcoholic drinks with information on how many units of alcohol they contain, e.g. "a pint of ordinary strength lager 
(Carling Black Label, Fosters) $=2$ units". They were then asked how many units of alcohol they would consume in a typical week and how many times they had engaged in binge drinking during the past week. Behavioural beliefs were measured by asking participants to state the advantages and what they would like or enjoy about drinking at least $7 / 10.5$ units of alcohol this evening. They were then asked about disadvantages and what they would dislike about drinking at least $7 / 10.5$ units of alcohol this evening. Normative beliefs were assessed by asking participants to indicate which individuals or groups would approve or disapprove of them drinking at least $7 / 10.5$ units of alcohol this evening. Control beliefs were assessed by asking participants to indicate which factors would make it easy or difficult for them to drink at least $7 / 10.5$ units of alcohol this evening.

The rest of the first questionnaire assessed standard Theory of Planned Behaviour constructs concerning drinking at least $7 / 10.5$ units of alcohol this evening, using 7 point rating scales. The resulting scales concerning attitudes ( 4 items, $\alpha=0.83$ ), subjective norms ( 4 items, $\alpha=0.67$ ), and intention ( 3 items, $\alpha=0.95$ ), e.g. were reliable, although the PBC scale ( 2 items, $\alpha=0.27$ ) had low internal consistency. Example items are as follows: Attitude: "for me to drink at least 7 units of alcohol this evening is: (bad-good)"; Subjective norm: "most people who are important to me would think that drinking at least 7 units of alcohol this evening is: (bad-good)"; PBC: "For me to drink at least 7 units of alcohol this evening would be: (possibleimpossible)"; Intention: “This evening I intend to drink at least 7 units of alcohol: (strongly disagree-strongly agree)."

The second questionnaire asked participants to list all the drinks they had consumed that evening and an aggregate measure of number of units of alcohol consumed was calculated.

\section{$\underline{\text { Analysis }}$}

Thirty of the questionnaires chosen at random were used to develop the coding frames for each of the eight questions. The beliefs for each question were put into categories and the same coding frame was used for the advantages and the like/enjoy questions. Similarly, coding frames were developed for the disadvantages and dislike/hate questions and the approve and disapprove questions, with separate coding frames for 
the easy and difficult questions. A sample of $20 \%$ of the questionnaires were coded by two researchers and Cohen`s Kappa indicated agreement: 'advantages` $(\kappa=0.95)$, ‘like/enjoy` $(\kappa=0.85)$, 'disadvantages` $(\kappa=0.94)$, 'dislike/hate` $(\kappa=0.91)$, ’approve` $(\kappa=0.88)$, 'disapprove` $(\kappa=0.79)$, ’easy` $(\kappa=0.83)$, 'difficult' $(\kappa=0.87)$.

Independent samples t-tests were carried out to compare the differences in mean scores of attitudes according to the presence or absence of each behavioural belief, differences in mean scores of subjective norms according to levels of each normative belief and differences in mean scores of PBC according to levels of each control belief. In addition, independent samples t-tests were carried out to compare the differences in mean scores of both intention and behaviour, according to the presence or absence of each belief.

A linear regression analysis was carried out, using intention as the dependent variable and perceived behavioural control, subjective norm and attitude as independent variables. A second analysis used drinking behaviour (number of units consumed) as the dependent variable and perceived behavioural control and intention as the independent variables.

Two further linear regressions were carried out, with intention and drinking behaviour as the dependent variables. In each case, those beliefs that were significantly related to the dependent variable in the previous bivariate analyses were independent variables.

\section{Results}

Over $72 \%$ of this sample of students reported that they had engaged in binge drinking in the week prior to the study. The most frequently mentioned advantage or what the participant would like about binge drinking was fun/ enjoyment, which was mentioned by 119 participants $(57.2 \%)$. The most frequently mentioned disadvantage or what the participant would dislike about binge drinking was having a hangover, mentioned by 142 (68.3\%) of the sample. The most frequently mentioned group of people who would approve of the participant binge drinking was friends, mentioned by $122(58.7 \%)$ of the participants. The most frequently mentioned group of people who would disapprove was family, mentioned by 114 (54.8\%). The most frequently 
mentioned factor that would make it easy to binge drink was having enough money or having drinks bought for them which was mentioned by 114 (54.8\%). The most frequently mentioned factor that would make it difficult to binge drink was lack of money, mentioned by 109 (52.4\%) of the participants.

Those participants who responded to questions about what they liked or thought were the advantages of binge drinking by providing beliefs about having fun, being sociable, and the effect on behaviour had significantly higher attitudes than those of participants who did not. Those participants who mentioned losing control in response to questions about what they disliked or thought were the disadvantages of binge drinking had significantly lower attitudes than those of participants who did not. Those participants who stated that there were no advantages to binge drinking had significantly lower attitudes than participants who cited at least one, whereas those participants who stated that there were no disadvantages to binge drinking had significantly higher attitudes than participants who cited at least one.

Significantly higher intention scores were found for participants who mentioned having fun, getting drunk and being sociable (as likes/ advantages), and did not mention spending money (as dislikes/ disadvantages). Significantly more alcohol was consumed by participants who earlier mentioned getting drunk, or who did not mention relaxation, as likes/ advantages.

Tables one and two about here

Those participants who mentioned family, friends and no one as approving of their binge drinking had significantly higher subjective norm scores. Those who mentioned friends and health professionals as disapproving had significantly lower subjective norm scores, although those who mentioned family as disapproving had significantly higher subjective norm scores. Those participants who mentioned friends as approving and family as disapproving had significantly higher intention scores. Significantly more alcohol was consumed by participants who earlier mentioned sports teams would approve and role models would disapprove.

Tables three and four about here 
Those participants who mentioned that being with friends would make it easy had significantly higher PBC scores, whereas those who mentioned lack of money as making it difficult to binge drink had lower PBC scores. Those participants who mentioned being ill or on medication as making binge drinking more difficult had significantly lower intention scores. Significantly more alcohol was consumed by participants who earlier mentioned that being in a good environment, celebrating and drinking games and modes of drinking would make it easy to binge drink.

Significantly more alcohol was also consumed by those who mentioned being ill or on medication as making it difficult to binge drink.

Tables five and six about here

Direct measures of attitudes $(\beta=0.42, \mathrm{p}<0.001)$ and subjective norms $(\beta=0.42, \mathrm{p}<$ $0.001)$ were significant predictors of intentions to binge drink. $\operatorname{PBC}(\beta=-0.09, p=$ $0.093)$ was not a significant predictor; adjusted $R^{2}$ was $0.55(F=74.6, d f=3,180$, $\mathrm{p}<0.001)$. Intention $(\beta=0.57, \mathrm{p}<0.001)$ was a significant predictor of drinking behaviour over the course of that evening. PBC was not a significant predictor $(\beta=$ $0.01, \mathrm{p}=0.870)$; adjusted $\mathrm{R}^{2}$ was $0.32(\mathrm{~F}=41.2, \mathrm{df}=2,173, \mathrm{p}<0.001)$.

When those seven beliefs that were significantly related to intention in bivariate analyses were entered into a linear regression, two were significant predictors of stronger intentions to binge drink: believing friends approve of binge drinking, and believing (lack of) money would make it difficult to binge drink (see Table 7). Similarly, when those eight beliefs that were significantly related to drinking behaviour in bivariate analyses were entered into a liner regression, five were significant predictors of higher alcohol consumption: believing getting drunk is enjoyable/ an advantage of binge drinking, believing sports teams approve, and believing that celebrating, drinking patterns, and environment would make it easy to binge drink (see Table 8).

Tables seven and eight about here 


\section{Discussion}

Over $72 \%$ of this sample of students reported that they had engaged in binge drinking at least once in the week prior to the survey. In bivariate analyses, several individually salient beliefs at the beginning of the evening were predictive of intentions to binge drink later that evening, and subsequent reports of alcohol consumption. In multivariate analyses, the normative belief that friends approve of binge drinking, and control belief that (lack of) money would make it difficult to binge drink significantly predicted intentions to binge drink. Similarly, the behavioural belief that getting drunk is enjoyable/ an advantage of binge drinking, the normative belief that sports teams approve of binge drinking, and the control beliefs that celebrating, drinking patterns and environment would make it easier to binge drink were predictive of subsequent alcohol consumption. Attitudes and subjective norm scores were found to predict intentions to binge drink and intention was found to predict drinking behaviour.

In the present study, both attitude towards binge drinking and subjective norm predict intention, which in turn is a strong predictor of behaviour. The results are consistent with other applications of the TPB to alcohol consumption in young people. First, the prediction of intentions by attitude and subjective norm, and the prediction of alcohol consumption by intentions is a common finding in this literature. More notably, it has been found in several studies that PBC is negatively associated to frequency of binge drinking (Armitage et al., 1999; Norman et al., 1998; Norman \& Conner, 2006), with those high in control engaging in more binge drinking. By contrast, other studies (e.g. Johnston \& White, 2003; McMillan \& Conner, 2003) found a positive association between PBC and frequency of binge drinking. The present study, which found no significant relationship between PBC and either intention and drinking behaviour is consistent with this mixed pattern of findings. For the present study, the lack of association between PBC and intention or behaviour may be explained by the low internal consistency of the PBC measure, and by a ceiling effect as a result of asking students in a bar about their control over drinking.

Two previous studies have examined beliefs towards binge drinking, but have reported the associations of these beliefs with other variables, as scales constructed of the modal belief set (Murgraff et al., 2001; Norman et al, 1998). Murgraff et al. 
(2001) found that, consistent with TPB predictions, more positive behavioural beliefs towards binge drinking were associated with higher frequency of such behaviour, and more negative normative beliefs (i.e. significant others would disapprove) were associated with a lower frequency of such behaviour. The results of Norman et al. (1998) were not consistent with TPB predictions, who found that more positive control beliefs (i.e. greater perceived control) were associated with higher rates of binge drinking. The implications that can be drawn from these studies, however, is limited due to analyses not being reported for specific individually salient beliefs, as in the present study.

There have now been numerous studies which have used the TPB to study alcohol consumption. However, these studies are limited in that they do not generally assess beliefs, which according to the author of the theory (Ajzen, 2007), are the ultimate psychological determinants of the behaviour and should be targeted by interventions to alter behaviour. The present study has identified those individually salient beliefs in a student sample which are predictive of intentions to binge drink, and binge drinking behaviour over the course of an evening.

In univariate analyses reported in tables 1 to 6 , a large number of individually salient beliefs were found to be significantly associated with directly measured attitudes, subjective norms, and $\mathrm{PBC}$, as well as intentions to binge drink, and actual drinking behaviour. It should be noted however, that given the large number of statistical tests performed, that one would expect several beliefs to be associated with these dependent variables, due to chance alone, so these analyses should be interpreted with caution.

At least partly due to the problems in interpreting multiple comparisons in univariate analyses, multivariate regression analyses were performed. These analyses identified which of those significant beliefs identified in the univariate analyses predicted significant amounts of variance entered together. Several beliefs were still significant predictors of intentions to binge drink (see table 7) and actual drinking behaviour (see table 8) in regression analyses, suggesting that the univariate results were not entirely spurious results of chance alone. Specifically those beliefs that predict alcohol consumption were that getting drunk is enjoyable/ an advantage of binge drinking, 
that sports teams approve of binge drinking, and that celebrating, drinking patterns and environment would make it easier to binge drink.

According to Sutton (2002), an intervention to alter attitudes could use one or more of the following strategies: (a) encouraging people to question how positive are the salient perceived positive consequences, (b) highlighting less salient negative consequences, to make these more salient, (c) encouraging people to question the likelihood that binge drinking would produce the perceived positive consequences, or (d) highlighting the likelihood that binge drinking would bring about perceived negative consequences.

The present research suggests that interventions to alter drinking behaviour via attitude change should aim to reduce the strength of students' belief that getting drunk is intrinsically enjoyable. Alternatively, such interventions could use information on the prevalence of negative behavioural beliefs to identify negative consequences of binge drinking that interventions could be made more salient (e.g. weight gain, losing control), and/ or address the perceived likelihood of these negative consequences occurring.

Similarly, interventions to alter drinking behaviour via changing subjective norms should aim to reduce the strength of students' beliefs that sports teams approve and of binge drinking behaviour. Alternatively, such interventions could focus on making less salient social referents who disapprove of binge drinking more salient (some friends and other students), or of addressing the perception that these social referents would approve of binge drinking in this context.

Similarly, interventions to alter drinking behaviour via changing PBC should aim to reduce the strength of students' beliefs that celebrating, drinking patterns and environment make binge drinking more easy. Alternatively, such interventions could focus on equipping students with the skills to cope with celebrations, drinking patterns such as buying rounds, and environments that encourage binge drinking.

Considering the beliefs as a whole, binge drinking is associated in this sample with celebrations, drinking patterns such as rounds, and encouraged by sports teams (who 
presumably celebrate victories and use drinking patterns to promote group coherence). These findings highlight the importance of perceived peer norms in binge drinking in this population. A Cochrane review recently concluded that challenging these often inaccurate perceptions in university-wide can lead to reduced perceptions of regular binge drinking as the norm, and consequently less binge drinking (Moreira, et al., 2009). The findings of the present research are consistent with this approach, and has identified the particular beliefs that it may be important for such interventions to address.

In conclusion, the present research has provided an empirical basis for TPB interventions to reduce binge drinking with UK students. Future research should aim to conduct pilot and full evaluations of such interventions, to test whether interventions derived from the theory is effective at reducing this behaviour. The present research could be used as a basis for both the intervention, and for modelling the effects of the intervention by providing the beliefs that a full TPB questionnaire should assess, and thereby allowing mediation analyses of the effects of the intervention. 


\section{References}

Agnew CR. (1998). Modal versus individually-derived beliefs about condom use: Measuring the cognitive underpinnings of the theory of reasoned action. Psychology and Health 13, 271-287.

Ajzen, I. (1991) The theory of planned behaviour. Organisational Behaviour and Human Decision Processes 50, 179-211

Ajzen, I. (2007) Behavioural Interventions based on the Theory of Planned Behaviour [online] available from $<$ http://www.people.umass.edu/aizen/pdf/tpb.intervention.pdf [11 July 2007]

Ajzen, I. \& Fishbein, M. (1977). Attitude-behavior relations: A theoretical analysis and review of empirical research. Psychological Bulletin 84, 888-918.

Ajzen I. \& Fishbein M. (2000). Attitudes and the attitude-behavior relation: Reasoned and automatic processes. European Review of Social Psychology 11, 1-33.

Armitage, C.J., Conner, M., Loach, J. \& Willetts, D. (1999). Different perceptions of control: Applying an extended theory of planned behaviour to legal and illegal drug use. Basic and Applied Social Psychology, 21, 301-316.

Armitage, C.J., Norman, P. \& Conner, M. (2002) Can the Theory of Planned Behaviour medicate the effects of age, gender and multidimensional health locus of control? British Journal of Health Psychology 7, 299-316

Babor, T. Caetano, P., Casswell, S., Edwards, G., Giesbrecht, N., Graham, K.,Grube, J.,Grunewald, W.P., Hill, L. \& Holder, H. (2003) Alcohol: No ordinary commodity. A summary of the book. Addiction 98, 1343-1350

Conner,M., \& Sparks, P. (2005). Theory of planned behaviour and health behaviour. In M. Conner \& P. Norman (Eds.), Predicting health behaviour (pp. 170222). Buckingham: Open University Press.

Conner, M., Warren, R., Close, S. \& Sparks, P. (1999) Alcohol consumption and the theory of planned behaviour: An examination of the cognitive mediation of past behaviour. Journal of Applied Social Psychology 29, 1676-1704

Cooke, R., Sniehotta, F. \& Schüz, B. (2007) Predicting binge-drinking behaviour using an extended TPB: Examining the impact of anticipated regret and descriptive norms. Alcohol and Alcoholism 42, 84-91.

Department of Health (1995). Sensible Drinking: the report of an interdepartment working group. London: Department of Health. 
Gill, J.S. (2002). Reported levels of alcohol consumption and binge drinking within the UK undergraduate student population over the last 25 years. Alcohol and Alcoholism 37, 109-120.

Johnston, K.L. \& White, K.M. (2003). Binge-drinking: A test of the role of group norms in the theory of planned behaviour. Psychology and Health 18, 63-77

Kaplan, K.J. \& Fishbein, M. (1969). The source of beliefs, their saliency, and prediction of attitude. Journal of Social Psychology 78, 63-74.

Lader, D. \& Steel, M. (2006) Drinking: adults` behaviour and knowledge in 2009. Opinions Survey Report number 42. London: Office for National Statistics.

McMillan, B. \& Conner, M. (2003). Using the theory of planned behaviour to understand alcohol and tobacco use in students. Psychology, Health and Medicine 8, 317-328.

Mokdad, A.H., Marks, J.S., Stroup, D.F. \& Gerberding, J.L. (2004) Actual causes of death in the United States 2000. Journal of the American Medical Association 291, 1238-1245.

Moreira, M.T., Smith L.A. \& Foxcroft, D. (2009). Social norms interventions to reduce alcohol misuse in University or College students. Cochrane Database of Systematic Reviews Issue 3. Art. No.: CD006748. DOI:

.1002/14651858.CD006748.pub2

Murgraff, V., McDermott, M.R. \& Walsh, J. (2001). Exploring attitude and belief correlates of adherence to the new guidelines for low-risk single-occasion drinking: an application of the theory of planned behaviour. Alcohol and Alcoholism, $36,135-140$.

Murgraff, V., Parrott, A. \& Bennett, P.(1999) Risky single-occasion drinking amongst young people - definition, correlates, policy and intervention: a broad overview of research findings. Alchohol and Alcoholism 36, 135-140

Norman, P., Bennett, P. \& Lewis, H. (1998) Understanding binge drinking among young people: An application of the Theory of Planned Behaviour. Health Education Research 13, 163-169

Norman, P. \& Conner, M. (2006) The theory of planned behaviour and binge drinking: Assessing the moderating role of past behaviour within the theory of planned behaviour. British Journal of Health Psychology 11, 55-70 
Norman, P., Armitage, C.J. \& Quigley, C. (2007). The theory of planned behavior and binge drinking: Assessing the impact of binge drinker prototypes. Addictive Behaviors 32, 1753-1768.

Steadman, L., Rutter, D.R. \& Field, S. (2002). Individually elicited versus modal normative beliefs in predicting attendance at breast screening: Examining the role of belief salience in the Theory of Planned Behaviour. British Journal of Health Psychology, 7, 317-330.

Sutton, S. (2002). Using social cognition models to develop health behaviour interventions: Problems and assumptions. In D. Rutter, \& L. Quine (Eds.), Changing health behaviour (pp. 193-208). Buckingham Philadelphia: Open University Press.

Sutton, S. (2010). Using social cognition models to develop health behaviour interventions: The theory of planned behaviour as an example. In D. French, K. Vedhara, A.A. Kaptein, \& J. Weinman (Eds.), Health Psychology (second edition, pp 122-134).

Sutton, S.R., French, D.P., Hennings, S.J., Mitchell, J., Wareham, N.J., Griffin, S.J., Hardeman, W. \& Kinmonth, A.L. (2003). Eliciting salient beliefs in research on the Theory of Planned Behaviour: The effect of question wording. Current Psychology 22, 229-246. 
Table one

Differences in attitudes, intentions and behaviour, according to presence or absence of salient positive behavioural beliefs

\begin{tabular}{|c|c|c|c|c|c|c|c|c|c|c|c|}
\hline Category & Yes & No & $\begin{array}{l}\text { Attitudes } \\
\text { Mean (SD) } \\
\text { yes }\end{array}$ & $\begin{array}{l}\text { Mean (SD) } \\
\text { no }\end{array}$ & $\begin{array}{l}\text { t-value } \\
\text { (sig) }\end{array}$ & $\begin{array}{l}\text { Intentions } \\
\text { Mean (SD) } \\
\text { yes }\end{array}$ & $\begin{array}{l}\text { Mean (SD) } \\
\text { no }\end{array}$ & $\begin{array}{l}\text { t-value } \\
\text { (sig) }\end{array}$ & $\begin{array}{l}\text { Behaviour } \\
\text { Mean (SD) } \\
\text { yes }\end{array}$ & $\begin{array}{l}\text { Mean (SD) } \\
\text { no }\end{array}$ & $\begin{array}{l}\text { t-value } \\
\text { (sig) }\end{array}$ \\
\hline Fun & 117 & 71 & $\begin{array}{l}18.786 \\
(4.690)\end{array}$ & $\begin{array}{l}15.732 \\
(6.243)\end{array}$ & $\begin{array}{l}3.81 \\
(<\mathbf{0 . 0 0 1})\end{array}$ & $\begin{array}{l}12.222 \\
(6.050)\end{array}$ & $\begin{array}{l}9.887 \\
(5.937)\end{array}$ & $\begin{array}{l}2.58 \\
(\mathbf{0 . 0 1 1})\end{array}$ & $\begin{array}{l}8.842 \\
(6.672)\end{array}$ & $\begin{array}{l}8.381 \\
(7.575)\end{array}$ & $\begin{array}{l}0.43 \\
(0.670)\end{array}$ \\
\hline Sociable & 96 & 92 & $\begin{array}{l}18.708 \\
(4.493)\end{array}$ & $\begin{array}{l}16.511 \\
(6.243)\end{array}$ & $\begin{array}{l}2.78 \\
(\mathbf{0 . 0 0 6 )}\end{array}$ & $\begin{array}{l}12.385 \\
(5.855)\end{array}$ & $\begin{array}{l}10.250 \\
(6.187)\end{array}$ & $\begin{array}{l}2.43 \\
(\mathbf{0 . 0 1 6})\end{array}$ & $\begin{array}{l}8.870 \\
(6.950)\end{array}$ & $\begin{array}{l}8.561 \\
(7.093)\end{array}$ & $\begin{array}{l}0.21 \\
(0.834)\end{array}$ \\
\hline Relaxation & 76 & 112 & $\begin{array}{l}17.513 \\
(5.355)\end{array}$ & $\begin{array}{l}17.714 \\
(5.646)\end{array}$ & $\begin{array}{l}0.747 \\
(0.807)\end{array}$ & $\begin{array}{l}10.487 \\
(5.615)\end{array}$ & $\begin{array}{l}11.920 \\
(6.365)\end{array}$ & $\begin{array}{l}0.159 \\
(0.114)\end{array}$ & $\begin{array}{l}7.093 \\
(4.930)\end{array}$ & $\begin{array}{l}9.788 \\
(7.993)\end{array}$ & $\begin{array}{l}2.59 \\
(\mathbf{0 . 0 1 0})\end{array}$ \\
\hline Effect on behaviour & 60 & 128 & $\begin{array}{l}18.933 \\
(5.256)\end{array}$ & $\begin{array}{l}17.023 \\
(5.551)\end{array}$ & $\begin{array}{l}2.24 \\
(\mathbf{0 . 0 2 7})\end{array}$ & $\begin{array}{l}12.350 \\
(6.000)\end{array}$ & $\begin{array}{l}10.867 \\
(6.110)\end{array}$ & $\begin{array}{l}1.56 \\
(0.120)\end{array}$ & $\begin{array}{l}9.060 \\
(7.275)\end{array}$ & $\begin{array}{l}8.488 \\
(6.893)\end{array}$ & $\begin{array}{l}0.51 \\
(0.609)\end{array}$ \\
\hline Confidence & 34 & 154 & $\begin{array}{l}17.353 \\
(5.438)\end{array}$ & $\begin{array}{l}17.695 \\
(5.550)\end{array}$ & $\begin{array}{l}0.33 \\
(0.745)\end{array}$ & $\begin{array}{l}12.265 \\
(6.793)\end{array}$ & $\begin{array}{l}11.136 \\
(5.939)\end{array}$ & $\begin{array}{l}0.98 \\
(0.330)\end{array}$ & $\begin{array}{l}10.833 \\
(8.523)\end{array}$ & $\begin{array}{l}8.242 \\
(6.609)\end{array}$ & $\begin{array}{l}1.86 \\
(0.064)\end{array}$ \\
\hline Getting drunk & 32 & 156 & $\begin{array}{l}18.094 \\
(4.707)\end{array}$ & $\begin{array}{l}17.539 \\
(5.678)\end{array}$ & $\begin{array}{l}0.52 \\
(0.605)\end{array}$ & $\begin{array}{l}13.273 \\
(6.414)\end{array}$ & $\begin{array}{l}10.929 \\
(5.970)\end{array}$ & $\begin{array}{l}2.02 \\
(\mathbf{0 . 0 4 5 )}\end{array}$ & $\begin{array}{l}11.552 \\
(7.912)\end{array}$ & $\begin{array}{l}8.122 \\
(6.704)\end{array}$ & $\begin{array}{l}2.45 \\
(\mathbf{0 . 0 1 5})\end{array}$ \\
\hline Taste & 15 & 173 & $\begin{array}{l}19.733 \\
(4.543)\end{array}$ & $\begin{array}{l}17.451 \\
(5.567)\end{array}$ & $\begin{array}{l}1.54 \\
(0.125)\end{array}$ & $\begin{array}{l}10.250 \\
(4.640)\end{array}$ & $\begin{array}{l}11.442 \\
(6.218)\end{array}$ & $\begin{array}{l}0.75 \\
(0.456)\end{array}$ & $\begin{array}{l}6.767 \\
(3.076)\end{array}$ & $\begin{array}{l}8.843 \\
(7.234)\end{array}$ & $\begin{array}{l}1.10 \\
(0.273)\end{array}$ \\
\hline Atmosphere & 15 & 173 & $\begin{array}{l}17.600 \\
(5.096)\end{array}$ & $\begin{array}{l}17.636 \\
(5.566)\end{array}$ & $\begin{array}{l}0.24 \\
(0.981)\end{array}$ & $\begin{array}{l}9.867 \\
(6.128)\end{array}$ & $\begin{array}{l}11.468 \\
(6.097)\end{array}$ & $\begin{array}{l}0.98 \\
(0.331)\end{array}$ & $\begin{array}{l}8.393 \\
(5.481)\end{array}$ & $\begin{array}{l}8.695 \\
(7.128)\end{array}$ & $\begin{array}{l}0.15 \\
(0.877)\end{array}$ \\
\hline $\begin{array}{l}\text { Same answer to previous } \\
\text { question }\end{array}$ & 12 & 176 & $\begin{array}{l}18.167 \\
(6.450)\end{array}$ & $\begin{array}{l}17.597 \\
(5.467)\end{array}$ & $\begin{array}{l}0.35 \\
(0.730)\end{array}$ & $\begin{array}{l}11.308 \\
(6.170)\end{array}$ & $\begin{array}{l}11.343 \\
(6.111)\end{array}$ & $\begin{array}{l}0.02 \\
(0.984)\end{array}$ & $\begin{array}{l}8.962 \\
(7.333)\end{array}$ & $\begin{array}{l}8.649 \\
(6.999)\end{array}$ & $\begin{array}{l}0.16 \\
(0.877)\end{array}$ \\
\hline No advantages/ likes & 20 & 168 & $\begin{array}{l}10.450 \\
(6.074)\end{array}$ & $\begin{array}{l}18.488 \\
(4.793)\end{array}$ & $\begin{array}{l}6.88 \\
(<\mathbf{0 . 0 0 1})\end{array}$ & $\begin{array}{l}5.500 \\
(3.395)\end{array}$ & $\begin{array}{l}12.036 \\
(5.980)\end{array}$ & $\begin{array}{l}4.79 \\
(<\mathbf{0 . 0 0 1})\end{array}$ & $\begin{array}{l}5.900 \\
(6.717)\end{array}$ & $\begin{array}{l}9.016 \\
(6.980)\end{array}$ & $\begin{array}{l}1.89 \\
(0.060)\end{array}$ \\
\hline No answer & 5 & 183 & $\begin{array}{l}10.800 \\
(6.380)\end{array}$ & $\begin{array}{l}17.820 \\
(5.391)\end{array}$ & $\begin{array}{l}2.86 \\
(\mathbf{0 . 0 0 5 )}\end{array}$ & $\begin{array}{l}4.200 \\
(2.168)\end{array}$ & $\begin{array}{l}11.536 \\
(6.055)\end{array}$ & $\begin{array}{l}2.70 \\
(\mathbf{0 . 0 0 8})\end{array}$ & $\begin{array}{l}3.583 \\
(3.323)\end{array}$ & $\begin{array}{l}8.846 \\
(7.035)\end{array}$ & $\begin{array}{l}1.82 \\
(0.070)\end{array}$ \\
\hline Miscellaneous & 35 & 153 & $\begin{array}{l}18.143 \\
(5.231)\end{array}$ & $\begin{array}{l}17.516 \\
(5.590)\end{array}$ & $\begin{array}{l}0.61 \\
(0.546)\end{array}$ & $\begin{array}{l}11.333 \\
(5.923)\end{array}$ & $\begin{array}{l}11.342 \\
(6.158)\end{array}$ & $\begin{array}{l}0.01 \\
(0.994)\end{array}$ & $\begin{array}{l}8.471 \\
(6.217)\end{array}$ & $\begin{array}{l}8.718 \\
(7.191)\end{array}$ & $\begin{array}{l}0.19 \\
(0.853)\end{array}$ \\
\hline
\end{tabular}

Behavioural beliefs elicited in response to questions about what participants thought were the advantages or what they would like or enjoy about drinking $10.5 / 7$ units of alcohol that evening. 
Table two

Differences in attitudes, intentions and behaviour, according to presence or absence of negative salient behavioural beliefs

\begin{tabular}{|c|c|c|c|c|c|c|c|c|c|c|c|}
\hline Category & Yes & No & $\begin{array}{l}\text { Attitudes } \\
\text { Mean (SD) } \\
\text { yes }\end{array}$ & $\begin{array}{l}\text { Mean (SD) } \\
\text { no }\end{array}$ & Significance & $\begin{array}{l}\text { Intention } \\
\text { Mean (SD) } \\
\text { yes }\end{array}$ & $\begin{array}{l}\text { Mean (SD) } \\
\text { no }\end{array}$ & Significance & $\begin{array}{l}\text { Behaviour } \\
\text { Mean (SD) } \\
\text { yes }\end{array}$ & $\begin{array}{l}\text { Mean (SD) } \\
\text { no }\end{array}$ & Significance \\
\hline Hangover & 138 & 50 & $\begin{array}{l}17.710 \\
(5.428)\end{array}$ & $\begin{array}{l}17.420 \\
(5.807)\end{array}$ & $\begin{array}{l}0.32 \\
(0.751)\end{array}$ & $\begin{array}{l}11.684 \\
(6.155)\end{array}$ & $\begin{array}{l}10.367 \\
(5.887)\end{array}$ & $\begin{array}{l}1.30 \\
(0.195)\end{array}$ & $\begin{array}{l}8.818 \\
(7.159)\end{array}$ & $\begin{array}{l}8.216 \\
(6.548)\end{array}$ & $\begin{array}{l}0.50 \\
(0.621)\end{array}$ \\
\hline Money & 88 & 100 & $\begin{array}{l}17.636 \\
(5.054)\end{array}$ & $\begin{array}{l}17.630 \\
(5.920)\end{array}$ & $\begin{array}{l}0.01 \\
(0.994)\end{array}$ & $\begin{array}{l}10.379 \\
(5.531)\end{array}$ & $\begin{array}{l}12.168 \\
(6.461)\end{array}$ & $\begin{array}{l}2.02 \\
(\mathbf{0 . 0 4 5})\end{array}$ & $\begin{array}{l}8.372 \\
(7.214)\end{array}$ & $\begin{array}{l}8.942 \\
(6.832)\end{array}$ & $\begin{array}{l}0.55 \\
(0.586)\end{array}$ \\
\hline Losing control & 60 & 128 & $\begin{array}{l}16.450 \\
(6.474)\end{array}$ & $\begin{array}{l}18.188 \\
(4.937)\end{array}$ & $\begin{array}{l}2.03 \\
(\mathbf{0 . 0 4 4})\end{array}$ & $\begin{array}{l}10.950 \\
(6.237)\end{array}$ & $\begin{array}{l}11.523 \\
(6.048)\end{array}$ & $\begin{array}{l}0.60 \\
(0.549)\end{array}$ & $\begin{array}{l}8.553 \\
(7.615)\end{array}$ & $\begin{array}{l}8.726 \\
(6.734)\end{array}$ & $\begin{array}{l}0.15 \\
(0.878)\end{array}$ \\
\hline Short term illness & 50 & 138 & $\begin{array}{l}17.480 \\
(5.926)\end{array}$ & $\begin{array}{l}17.688 \\
(5.383)\end{array}$ & $\begin{array}{l}0.23 \\
(0.820)\end{array}$ & $\begin{array}{l}11.900 \\
(6.478)\end{array}$ & $\begin{array}{l}11.138 \\
(5.966)\end{array}$ & $\begin{array}{l}0.76 \\
(0.450)\end{array}$ & $\begin{array}{l}8.078 \\
(7.015)\end{array}$ & $\begin{array}{l}8.904 \\
(7.011)\end{array}$ & $\begin{array}{l}0.71 \\
(0.477)\end{array}$ \\
\hline Regret & 44 & 144 & $\begin{array}{l}17.432 \\
(5.555)\end{array}$ & $\begin{array}{l}17.694 \\
(5.523)\end{array}$ & $\begin{array}{l}0.28 \\
(0.783)\end{array}$ & $\begin{array}{l}11.311 \\
(6.222)\end{array}$ & $\begin{array}{l}11.350 \\
(6.081)\end{array}$ & $\begin{array}{l}0.04 \\
(0.071)\end{array}$ & $\begin{array}{l}8.864 \\
(7.561)\end{array}$ & $\begin{array}{l}8.610 \\
(6.842)\end{array}$ & $\begin{array}{l}0.21 \\
(0.835)\end{array}$ \\
\hline Commitments & 34 & 154 & $\begin{array}{l}17.647 \\
(5.063)\end{array}$ & $\begin{array}{l}17.630 \\
(5.628)\end{array}$ & $\begin{array}{l}0.02 \\
(0.987)\end{array}$ & $\begin{array}{l}11.706 \\
(5.755)\end{array}$ & $\begin{array}{l}11.260 \\
(6.186)\end{array}$ & $\begin{array}{l}0.39 \\
(0.701)\end{array}$ & $\begin{array}{l}9.952 \\
(7.900)\end{array}$ & $\begin{array}{l}8.407 \\
(6.801)\end{array}$ & $\begin{array}{l}1.12 \\
(0.265)\end{array}$ \\
\hline $\begin{array}{l}\text { Long term health } \\
\text { problems }\end{array}$ & 31 & 157 & $\begin{array}{l}17.419 \\
(4.71)\end{array}$ & $\begin{array}{l}17.675 \\
(5.675)\end{array}$ & $\begin{array}{l}0.24 \\
(0.814)\end{array}$ & $\begin{array}{l}10.546 \\
(5.518)\end{array}$ & $\begin{array}{l}11.510 \\
(6.218)\end{array}$ & $\begin{array}{l}0.83 \\
(0.411)\end{array}$ & $\begin{array}{l}9.717 \\
(8.425)\end{array}$ & $\begin{array}{l}8.464 \\
(6.698)\end{array}$ & $\begin{array}{l}0.90 \\
(0.372)\end{array}$ \\
\hline Weight gain & 20 & 168 & $\begin{array}{l}18.950 \\
(5.744)\end{array}$ & $\begin{array}{l}17.476 \\
(5.486)\end{array}$ & $\begin{array}{l}1.13 \\
(0.260)\end{array}$ & $\begin{array}{l}12.900 \\
(6.290)\end{array}$ & $\begin{array}{l}11.155 \\
(6.067)\end{array}$ & $\begin{array}{l}1.21 \\
(0.227)\end{array}$ & $\begin{array}{l}6.737 \\
(4.617)\end{array}$ & $\begin{array}{l}8.898 \\
(7.207)\end{array}$ & $\begin{array}{l}1.28 \\
(0.204)\end{array}$ \\
\hline $\begin{array}{l}\text { Same answer to } \\
\text { similar question }\end{array}$ & 16 & 172 & $\begin{array}{l}14.875 \\
(6.692)\end{array}$ & $\begin{array}{l}17.890 \\
(5.346)\end{array}$ & $\begin{array}{l}2.11 \\
(\mathbf{0 . 0 3 6})\end{array}$ & $\begin{array}{l}8.625 \\
(6.365)\end{array}$ & $\begin{array}{l}11.593 \\
(6.030)\end{array}$ & $\begin{array}{l}1.88 \\
(0.062)\end{array}$ & $\begin{array}{l}7.750 \\
(7.708)\end{array}$ & $\begin{array}{l}8.749 \\
(6.960)\end{array}$ & $\begin{array}{l}0.51 \\
(0.610)\end{array}$ \\
\hline $\begin{array}{l}\text { No disadvantages/ } \\
\text { dislikes }\end{array}$ & 8 & 180 & $\begin{array}{l}21.500 \\
(5.014)\end{array}$ & $\begin{array}{l}17.461 \\
(5.488)\end{array}$ & $\begin{array}{l}2.04 \\
(\mathbf{0 . 0 4 2})\end{array}$ & $\begin{array}{l}15.625 \\
(4.749)\end{array}$ & $\begin{array}{l}11.150 \\
(6.092)\end{array}$ & $\begin{array}{l}2.05 \\
(\mathbf{0 . 0 4 2})\end{array}$ & $\begin{array}{l}8.318 \\
(6.071)\end{array}$ & $\begin{array}{l}8.688 \\
(7.058)\end{array}$ & $\begin{array}{l}0.15 \\
(0.883)\end{array}$ \\
\hline No answer & 10 & 178 & $\begin{array}{l}15.700 \\
(5.012)\end{array}$ & $\begin{array}{l}17.742 \\
(5.537)\end{array}$ & $\begin{array}{l}1.14 \\
(0.256)\end{array}$ & $\begin{array}{l}9.500 \\
(5.836)\end{array}$ & $\begin{array}{l}11.444 \\
(6.112)\end{array}$ & $\begin{array}{l}0.98 \\
(0.328)\end{array}$ & $\begin{array}{l}8.300 \\
(6.206)\end{array}$ & $\begin{array}{l}8.693 \\
(7.062)\end{array}$ & $\begin{array}{l}0.17 \\
(0.864)\end{array}$ \\
\hline Miscellaneous & 32 & 156 & $\begin{array}{l}16.531 \\
(5.858)\end{array}$ & $\begin{array}{l}17.859 \\
(5.436)\end{array}$ & $\begin{array}{l}1.24 \\
(0.216)\end{array}$ & $\begin{array}{l}10.970 \\
(6.342)\end{array}$ & $\begin{array}{l}11.419 \\
(6.063)\end{array}$ & $\begin{array}{l}0.38 \\
(0.702)\end{array}$ & $\begin{array}{l}8.586 \\
(7.432)\end{array}$ & $\begin{array}{l}8.688 \\
(6.943)\end{array}$ & $\begin{array}{l}0.07 \\
(0.943)\end{array}$ \\
\hline
\end{tabular}

Behavioural beliefs elicited in response to questions about what participants thought were the disadvantages or what they would dislike about drinking $10.5 / 7$ units of alcohol that evening. 
Table three

Differences in subjective norms, intentions and behaviour, according to presence or absence of salient positive normative beliefs

\begin{tabular}{|c|c|c|c|c|c|c|c|c|c|c|c|}
\hline Category & Yes & No & $\begin{array}{l}\text { Subj Norm } \\
\text { Mean (SD) } \\
\text { yes }\end{array}$ & $\begin{array}{l}\text { Mean (SD) } \\
\text { no }\end{array}$ & Significance & $\begin{array}{l}\text { Intention } \\
\text { Mean (SD) } \\
\text { yes }\end{array}$ & $\begin{array}{l}\text { Mean (SD) } \\
\text { no }\end{array}$ & Significance & $\begin{array}{l}\text { Behaviour } \\
\text { Mean (SD) } \\
\text { yes }\end{array}$ & $\begin{array}{l}\text { Mean (SD) } \\
\text { no }\end{array}$ & Significance \\
\hline Friends & 121 & 69 & $\begin{array}{l}18.050 \\
(5.059)\end{array}$ & $\begin{array}{l}15.362 \\
(4.693)\end{array}$ & $\begin{array}{l}3.61 \\
(<\mathbf{0 . 0 0 1})\end{array}$ & $\begin{array}{l}12.496 \\
(6.105)\end{array}$ & $\begin{array}{l}9.348 \\
(5.588)\end{array}$ & $\begin{array}{l}3.51 \\
(\mathbf{0 . 0 0 1})\end{array}$ & $\begin{array}{l}9.259 \\
(7.210)\end{array}$ & $\begin{array}{l}7.672 \\
(6.566)\end{array}$ & $\begin{array}{l}1.48 \\
(0.141)\end{array}$ \\
\hline Drink companies & 33 & 157 & $\begin{array}{l}17.242 \\
(5.268)\end{array}$ & $\begin{array}{l}17.038 \\
(5.062)\end{array}$ & $\begin{array}{l}0.21 \\
(0.835)\end{array}$ & $\begin{array}{l}11.485 \\
(6.286)\end{array}$ & $\begin{array}{l}11.310 \\
(6.078)\end{array}$ & $\begin{array}{l}0.15 \\
(0.881)\end{array}$ & $\begin{array}{l}8.424 \\
(6.447)\end{array}$ & $\begin{array}{l}8.726 \\
(7.140)\end{array}$ & $\begin{array}{l}0.22 \\
(0.833)\end{array}$ \\
\hline Teams & 23 & 167 & $\begin{array}{l}18.435 \\
(5.647)\end{array}$ & $\begin{array}{l}16.886 \\
(4.992)\end{array}$ & $\begin{array}{l}1.37 \\
(0.172)\end{array}$ & $\begin{array}{l}12.591 \\
(6.522)\end{array}$ & $\begin{array}{l}11.175 \\
(6.041)\end{array}$ & $\begin{array}{l}1.02 \\
(0.307)\end{array}$ & $\begin{array}{l}14.100 \\
(10.407)\end{array}$ & $\begin{array}{l}7.997 \\
(6.177)\end{array}$ & $\begin{array}{l}3.81 \\
(<\mathbf{0 . 0 0 1})\end{array}$ \\
\hline Family & 13 & 177 & $\begin{array}{l}19.846 \\
(4.879)\end{array}$ & $\begin{array}{l}16.870 \\
(5.053)\end{array}$ & $\begin{array}{l}2.05 \\
(\mathbf{0 . 0 4 1})\end{array}$ & $\begin{array}{l}14.308 \\
(6.047)\end{array}$ & $\begin{array}{l}11.120 \\
(6.061)\end{array}$ & $\begin{array}{l}1.83 \\
(0.069)\end{array}$ & $\begin{array}{l}10.750 \\
(7.497)\end{array}$ & $\begin{array}{l}8.524 \\
(6.966)\end{array}$ & $\begin{array}{l}1.07 \\
(0.288)\end{array}$ \\
\hline Students & 12 & 178 & $\begin{array}{l}16.167 \\
(3.713)\end{array}$ & $\begin{array}{l}17.135 \\
(5.167)\end{array}$ & $\begin{array}{l}0.64 \\
(0.525)\end{array}$ & $\begin{array}{l}9.667 \\
(5.015)\end{array}$ & $\begin{array}{l}11.455 \\
(6.161)\end{array}$ & $\begin{array}{l}0.98 \\
(0.327)\end{array}$ & $\begin{array}{l}7.636 \\
(3.392)\end{array}$ & $\begin{array}{l}8.738 \\
(7.174)\end{array}$ & $\begin{array}{l}0.51 \\
(0.614)\end{array}$ \\
\hline Health professionals & 5 & 185 & $\begin{array}{l}18.000 \\
(2.739)\end{array}$ & $\begin{array}{l}17.049 \\
(5.135)\end{array}$ & $\begin{array}{l}0.41 \\
(0.681)\end{array}$ & $\begin{array}{l}12.600 \\
(4.879)\end{array}$ & $\begin{array}{l}11.306 \\
(6.135)\end{array}$ & $\begin{array}{l}0.47 \\
(0.641)\end{array}$ & $\begin{array}{l}9.500 \\
(4.062)\end{array}$ & $\begin{array}{l}8.648 \\
(7.074)\end{array}$ & $\begin{array}{l}0.27 \\
(0.791)\end{array}$ \\
\hline Role models & 2 & 188 & $\begin{array}{l}20.000 \\
(2.828)\end{array}$ & $\begin{array}{l}17.043 \\
(5.099)\end{array}$ & $\begin{array}{l}0.82 \\
(0.415)\end{array}$ & $\begin{array}{l}17.500 \\
(4.950)\end{array}$ & $\begin{array}{l}11.274 \\
(6.086)\end{array}$ & $\begin{array}{l}1.44 \\
(0.151)\end{array}$ & $\begin{array}{l}13.000 \\
(7.071)\end{array}$ & $\begin{array}{l}8.623 \\
(7.007)\end{array}$ & $\begin{array}{l}0.88 \\
(0.381)\end{array}$ \\
\hline Non-drinkers & 1 & 189 & 18.000 & $\begin{array}{l}17.069 \\
(5.098)\end{array}$ & $\begin{array}{l}0.18 \\
(0.856)\end{array}$ & 14.000 & $\begin{array}{l}11.326 \\
(6.111)\end{array}$ & $\begin{array}{l}0.44 \\
(0.663)\end{array}$ & 8.000 & $\begin{array}{l}8.675 \\
(7.022)\end{array}$ & $\begin{array}{l}0.10 \\
(0.924)\end{array}$ \\
\hline Yes & 10 & 180 & $\begin{array}{l}15.900 \\
(4.483)\end{array}$ & $\begin{array}{l}17.139 \\
(5.120)\end{array}$ & $\begin{array}{l}0.75 \\
(0.455)\end{array}$ & $\begin{array}{l}7.900 \\
(3.348)\end{array}$ & $\begin{array}{l}11.534 \\
(6.165)\end{array}$ & $\begin{array}{l}1.85 \\
(0.067)\end{array}$ & $\begin{array}{l}4.667 \\
(5.657)\end{array}$ & $\begin{array}{l}8.881 \\
(7.016)\end{array}$ & $\begin{array}{l}1.77 \\
(0.078)\end{array}$ \\
\hline No & 21 & 169 & $\begin{array}{l}14.381 \\
(4.811)\end{array}$ & $\begin{array}{l}17.408 \\
(5.031)\end{array}$ & $\begin{array}{l}2.61 \\
(\mathbf{0 . 0 1 0})\end{array}$ & $\begin{array}{l}9.333 \\
(5.304)\end{array}$ & $\begin{array}{l}11.593 \\
(6.159)\end{array}$ & $\begin{array}{l}1.61 \\
(0.110)\end{array}$ & $\begin{array}{l}9.119 \\
(6.812)\end{array}$ & $\begin{array}{l}8.613 \\
(7.046)\end{array}$ & $\begin{array}{l}0.31 \\
(0.756)\end{array}$ \\
\hline No answer & 5 & 185 & $\begin{array}{l}13.200 \\
(3.834)\end{array}$ & $\begin{array}{l}17.178 \\
(5.081)\end{array}$ & $\begin{array}{l}1.74 \\
(0.084)\end{array}$ & $\begin{array}{l}8.200 \\
(5.404)\end{array}$ & $\begin{array}{l}11.426 \\
(6.107)\end{array}$ & $\begin{array}{l}1.17 \\
(0.244)\end{array}$ & $\begin{array}{l}7.667 \\
(8.914)\end{array}$ & $\begin{array}{l}8.706 \\
(6.957)\end{array}$ & $\begin{array}{l}0.36 \\
(0.722)\end{array}$ \\
\hline Miscellaneous & 19 & 171 & $\begin{array}{l}17.737 \\
(4.817)\end{array}$ & $\begin{array}{l}17.000 \\
(5.122)\end{array}$ & $\begin{array}{l}0.60 \\
(0.550)\end{array}$ & $\begin{array}{l}11.368 \\
(5.918)\end{array}$ & $\begin{array}{l}11.337 \\
(6.135)\end{array}$ & $\begin{array}{l}0.02 \\
(0.983)\end{array}$ & $\begin{array}{l}8.765 \\
(7.308)\end{array}$ & $\begin{array}{l}8.662 \\
(6.993)\end{array}$ & $\begin{array}{l}0.06 \\
(0.954)\end{array}$ \\
\hline
\end{tabular}

Normative beliefs elicited in response to question about who the participants thought would approve of them drinking $10.5 / 7$ units of alcohol that evening. 
Table four

Differences in subjective norms, intentions and behaviour, according to presence or absence of salient negative normative beliefs

\begin{tabular}{|c|c|c|c|c|c|c|c|c|c|c|c|}
\hline Category & Yes & No & $\begin{array}{l}\text { Subj Norm } \\
\text { Mean (SD) } \\
\text { yes }\end{array}$ & $\begin{array}{l}\text { Mean (SD) } \\
\text { no }\end{array}$ & Significance & $\begin{array}{l}\text { Intention } \\
\text { Mean (SD) } \\
\text { yes }\end{array}$ & $\begin{array}{l}\text { Mean (SD) } \\
\text { no }\end{array}$ & Significance & $\begin{array}{l}\text { Behaviour } \\
\text { Mean (SD) } \\
\text { yes }\end{array}$ & $\begin{array}{l}\text { Mean (SD) } \\
\text { no }\end{array}$ & Significance \\
\hline Family & 112 & 78 & $\begin{array}{l}17.777 \\
(5.015)\end{array}$ & $\begin{array}{l}16.064 \\
(5.046)\end{array}$ & $\begin{array}{l}2.31 \\
(\mathbf{0 . 0 2 2})\end{array}$ & $\begin{array}{l}12.227 \\
(5.896)\end{array}$ & $\begin{array}{l}10.090 \\
(6.196)\end{array}$ & $\begin{array}{l}2.49 \\
(\mathbf{0 . 0 1 7})\end{array}$ & $\begin{array}{l}8.649 \\
(6.853)\end{array}$ & $\begin{array}{l}8.707 \\
(7.284)\end{array}$ & $\begin{array}{l}0.06 \\
(0.957)\end{array}$ \\
\hline Role models & 44 & 146 & $\begin{array}{l}18.250 \\
(5.177)\end{array}$ & $\begin{array}{l}16.719 \\
(5.021)\end{array}$ & $\begin{array}{l}1.76 \\
(0.080)\end{array}$ & $\begin{array}{l}12.581 \\
(6.594)\end{array}$ & $\begin{array}{l}10.972 \\
(5.917)\end{array}$ & $\begin{array}{l}1.53 \\
(0.129)\end{array}$ & $\begin{array}{l}10.547 \\
(8.628)\end{array}$ & $\begin{array}{l}8.087 \\
(6.337)\end{array}$ & $\begin{array}{l}2.03 \\
(\mathbf{0 . 0 4 4 )}\end{array}$ \\
\hline Non-drinkers & 22 & 168 & $\begin{array}{l}16.454 \\
(4.626)\end{array}$ & $\begin{array}{l}17.155 \\
(5.149)\end{array}$ & $\begin{array}{l}0.61 \\
(0.545)\end{array}$ & $\begin{array}{l}10.182 \\
(5.207)\end{array}$ & $\begin{array}{l}11.494 \\
(6.204)\end{array}$ & $\begin{array}{l}0.95 \\
(0.344)\end{array}$ & $\begin{array}{l}7.611 \\
(3.763)\end{array}$ & $\begin{array}{l}8.788 \\
(7.270)\end{array}$ & $\begin{array}{l}0.68 \\
(0.500)\end{array}$ \\
\hline $\begin{array}{l}\text { Health } \\
\text { professionals }\end{array}$ & 19 & 171 & $\begin{array}{l}14.895 \\
(4.806)\end{array}$ & $\begin{array}{l}17.316 \\
(5.071)\end{array}$ & $\begin{array}{l}1.98 \\
(\mathbf{0 . 0 4 9 )}\end{array}$ & $\begin{array}{l}12.211 \\
(5.702)\end{array}$ & $\begin{array}{l}11.243 \\
(6.149)\end{array}$ & $\begin{array}{l}0.66 \\
(0.513)\end{array}$ & $\begin{array}{l}8.441 \\
(5.876)\end{array}$ & $\begin{array}{l}8.695 \\
(7.124)\end{array}$ & $\begin{array}{l}0.14 \\
(0.887)\end{array}$ \\
\hline Friends & 14 & 176 & $\begin{array}{l}14.500 \\
(5.080)\end{array}$ & $\begin{array}{l}17.278 \\
(5.043)\end{array}$ & $\begin{array}{l}1.98 \\
(\mathbf{0 . 0 4 9 )}\end{array}$ & $\begin{array}{l}8.857 \\
(5.246)\end{array}$ & $\begin{array}{l}11.540 \\
(6.131)\end{array}$ & $\begin{array}{l}1.59 \\
(0.113)\end{array}$ & $\begin{array}{l}6.500 \\
(7.654)\end{array}$ & $\begin{array}{l}8.853 \\
(6.939)\end{array}$ & $\begin{array}{l}1.21 \\
(0.288)\end{array}$ \\
\hline Drink companies & 3 & 187 & $\begin{array}{l}17.000 \\
(5.196)\end{array}$ & $\begin{array}{l}17.075 \\
(5.097)\end{array}$ & $\begin{array}{l}0.03 \\
(0.980)\end{array}$ & $\begin{array}{l}13.333 \\
(5.508)\end{array}$ & $\begin{array}{l}11.308 \\
(6.115)\end{array}$ & $\begin{array}{l}0.57 \\
(0.570)\end{array}$ & $\begin{array}{l}7.000 \\
(7.550)\end{array}$ & $\begin{array}{l}8.699 \\
(7.012)\end{array}$ & $\begin{array}{l}0.42 \\
(0.678)\end{array}$ \\
\hline Teams & 2 & 188 & $\begin{array}{l}17.000 \\
(5.657)\end{array}$ & $\begin{array}{l}17.075 \\
(5.095)\end{array}$ & $\begin{array}{l}0.02 \\
(0.984)\end{array}$ & $\begin{array}{l}9.500 \\
(0.707)\end{array}$ & $\begin{array}{l}11.360 \\
(6.128)\end{array}$ & $\begin{array}{l}0.43 \\
(0.669)\end{array}$ & $\begin{array}{l}8.500 \\
(3.536)\end{array}$ & $\begin{array}{l}8.673 \\
(7.037)\end{array}$ & $\begin{array}{l}0.04 \\
(0.972)\end{array}$ \\
\hline Students & 0 & 190 & & $\begin{array}{l}17.074 \\
(5.085)\end{array}$ & & & $\begin{array}{l}11.340 \\
(6.098)\end{array}$ & & & $\begin{array}{l}8.671 \\
(7.002)\end{array}$ & \\
\hline Yes & 7 & 183 & $\begin{array}{l}13.286 \\
(2.984)\end{array}$ & $\begin{array}{l}17.316 \\
(5.098)\end{array}$ & $\begin{array}{l}2.03 \\
(\mathbf{0 . 0 4 4 )}\end{array}$ & $\begin{array}{l}9.714 \\
(4.071)\end{array}$ & $\begin{array}{l}11.403 \\
(6.162)\end{array}$ & $\begin{array}{l}0.72 \\
(0.474)\end{array}$ & $\begin{array}{l}7.500 \\
(4.087)\end{array}$ & $\begin{array}{l}8.711 \\
(7.085)\end{array}$ & $\begin{array}{l}0.42 \\
(0.678)\end{array}$ \\
\hline No & 22 & 168 & $\begin{array}{l}17.636 \\
(5.095)\end{array}$ & $\begin{array}{l}17.000 \\
(5.094)\end{array}$ & $\begin{array}{l}0.55 \\
(0.582)\end{array}$ & $\begin{array}{l}10.955 \\
(6.786)\end{array}$ & $\begin{array}{l}11.392 \\
(6.022)\end{array}$ & $\begin{array}{l}0.32 \\
(0.753)\end{array}$ & $\begin{array}{l}7.429 \\
(7.001)\end{array}$ & $\begin{array}{l}8.834 \\
(7.008)\end{array}$ & $\begin{array}{l}0.86 \\
(0.389)\end{array}$ \\
\hline No answer & 9 & 181 & $\begin{array}{l}14.444 \\
(4.157)\end{array}$ & $\begin{array}{l}17.204 \\
(5.101)\end{array}$ & $\begin{array}{l}1.60 \\
(0.112)\end{array}$ & $\begin{array}{l}9.889 \\
(6.772)\end{array}$ & $\begin{array}{l}11.413 \\
(6.074)\end{array}$ & $\begin{array}{l}0.74 \\
(0.466)\end{array}$ & $\begin{array}{l}11.813 \\
(8.750)\end{array}$ & $\begin{array}{l}8.526 \\
(6.908)\end{array}$ & $\begin{array}{l}1.30 \\
(0.195)\end{array}$ \\
\hline Miscellaneous & 19 & 171 & $\begin{array}{l}16.000 \\
(4.955)\end{array}$ & $\begin{array}{l}17.193 \\
(5.099)\end{array}$ & $\begin{array}{l}0.97 \\
(0.333)\end{array}$ & $\begin{array}{l}9.895 \\
(6.437)\end{array}$ & $\begin{array}{l}11.503 \\
(6.057)\end{array}$ & $\begin{array}{l}1.09 \\
(0.277)\end{array}$ & $\begin{array}{l}7.941 \\
(8.156) \\
\end{array}$ & $\begin{array}{l}8.747 \\
(6.896)\end{array}$ & $\begin{array}{l}0.45 \\
(0.806)\end{array}$ \\
\hline
\end{tabular}


Table five

Differences in PBC, intentions and behaviour, according to presence or absence of salient positive control beliefs

\begin{tabular}{|c|c|c|c|c|c|c|c|c|c|c|c|}
\hline Category & Yes & No & $\begin{array}{l}\text { PBC } \\
\text { Mean (SD) } \\
\text { yes }\end{array}$ & $\begin{array}{l}\text { Mean (SD) } \\
\text { no }\end{array}$ & Significance & $\begin{array}{l}\text { Intention } \\
\text { Mean (SD) } \\
\text { yes }\end{array}$ & $\begin{array}{l}\text { Mean (SD) } \\
\text { no }\end{array}$ & Significance & $\begin{array}{l}\text { Behaviour } \\
\text { Mean (SD) } \\
\text { yes } \\
\end{array}$ & $\begin{array}{l}\text { Mean (SD) } \\
\text { no }\end{array}$ & Significance \\
\hline Money & 112 & 76 & $\begin{array}{l}12.589 \\
(2.534)\end{array}$ & $\begin{array}{l}12.526 \\
(1.887)\end{array}$ & $\begin{array}{l}0.25 \\
(0.802)\end{array}$ & $\begin{array}{l}11.107 \\
(6.039)\end{array}$ & $\begin{array}{l}11.684 \\
(6.208)\end{array}$ & $\begin{array}{l}0.64 \\
(0.526)\end{array}$ & $\begin{array}{l}8.347 \\
(7.230)\end{array}$ & $\begin{array}{l}9.151 \\
(6.672)\end{array}$ & $\begin{array}{l}0.76 \\
(0.450)\end{array}$ \\
\hline Social influences & 43 & 145 & $\begin{array}{l}12.209 \\
(1.909)\end{array}$ & $\begin{array}{l}12.669 \\
(1.599)\end{array}$ & $\begin{array}{l}1.58 \\
(0.116)\end{array}$ & $\begin{array}{l}10.705 \\
(5.437)\end{array}$ & $\begin{array}{l}11.535 \\
(6.291)\end{array}$ & $\begin{array}{l}0.79 \\
(0.431)\end{array}$ & $\begin{array}{l}7.138 \\
(5.632)\end{array}$ & $\begin{array}{l}9.106 \\
(7.304)\end{array}$ & $\begin{array}{l}1.58 \\
(0.117)\end{array}$ \\
\hline Environment & 34 & 154 & $\begin{array}{l}12.706 \\
(2.023)\end{array}$ & $\begin{array}{l}12.533 \\
(1.601)\end{array}$ & $\begin{array}{l}0.54 \\
(0.587)\end{array}$ & $\begin{array}{l}11.794 \\
(6.700)\end{array}$ & $\begin{array}{l}11.240 \\
(5.976)\end{array}$ & $\begin{array}{l}0.48 \\
(0.633)\end{array}$ & $\begin{array}{l}11.424 \\
(9.075)\end{array}$ & $\begin{array}{l}8.057 \\
(6.327)\end{array}$ & $\begin{array}{l}2.54 \\
(\mathbf{0 . 0 1 2})\end{array}$ \\
\hline Celebration & 30 & 158 & $\begin{array}{l}12.267 \\
(1.057)\end{array}$ & $\begin{array}{l}12.620 \\
(1.699)\end{array}$ & $\begin{array}{l}1.06 \\
(0.292)\end{array}$ & $\begin{array}{l}12.103 \\
(5.960)\end{array}$ & $\begin{array}{l}11.201 \\
(6.131)\end{array}$ & $\begin{array}{l}0.73 \\
(0.465)\end{array}$ & $\begin{array}{l}11.839 \\
(7.806)\end{array}$ & $\begin{array}{l}8.092 \\
(6.712)\end{array}$ & $\begin{array}{l}2.65 \\
(\mathbf{0 . 0 0 9 )}\end{array}$ \\
\hline $\begin{array}{l}\text { No } \\
\text { commitments }\end{array}$ & 26 & 162 & $\begin{array}{l}12.692 \\
(1.594)\end{array}$ & $\begin{array}{l}12.543 \\
(1.698)\end{array}$ & $\begin{array}{l}0.42 \\
(0.676)\end{array}$ & $\begin{array}{l}10.385 \\
(6.073)\end{array}$ & $\begin{array}{l}11.494 \\
(6.107)\end{array}$ & $\begin{array}{l}0.86 \\
(0.391)\end{array}$ & $\begin{array}{l}7.769 \\
(5.054)\end{array}$ & $\begin{array}{l}8.823 \\
(7.281)\end{array}$ & $\begin{array}{l}0.71 \\
(0.479)\end{array}$ \\
\hline $\begin{array}{l}\text { Drinking } \\
\text { patterns }\end{array}$ & 23 & 165 & $\begin{array}{l}12.870 \\
(1.424)\end{array}$ & $\begin{array}{l}12.521 \\
(1.713)\end{array}$ & $\begin{array}{l}0.93 \\
(0.353)\end{array}$ & $\begin{array}{l}12.044 \\
(6.677)\end{array}$ & $\begin{array}{l}11.242 \\
(6.029)\end{array}$ & $\begin{array}{l}0.59 \\
(0.556)\end{array}$ & $\begin{array}{l}11.614 \\
(8.447)\end{array}$ & $\begin{array}{l}8.264 \\
(6.709)\end{array}$ & $\begin{array}{l}2.12 \\
(\mathbf{0 . 0 3 5 )}\end{array}$ \\
\hline With friends & 22 & 166 & $\begin{array}{l}11.864 \\
(1.754)\end{array}$ & $\begin{array}{l}12.657 \\
(1.654)\end{array}$ & $\begin{array}{l}2.10 \\
(\mathbf{0 . 0 3 7})\end{array}$ & $\begin{array}{l}12.650 \\
(6.491)\end{array}$ & $\begin{array}{l}11.185 \\
(6.051)\end{array}$ & $\begin{array}{l}1.02 \\
(0.311)\end{array}$ & $\begin{array}{l}8.796 \\
(8.051)\end{array}$ & $\begin{array}{l}8.654 \\
(6.873)\end{array}$ & $\begin{array}{l}0.09 \\
(0.930)\end{array}$ \\
\hline $\begin{array}{l}\text { To forget bad } \\
\text { things }\end{array}$ & 22 & 166 & $\begin{array}{l}12.636 \\
(1.432)\end{array}$ & $\begin{array}{l}12.554 \\
(1.714)\end{array}$ & $\begin{array}{l}0.22 \\
(0.830)\end{array}$ & $\begin{array}{l}10.381 \\
(5.408)\end{array}$ & $\begin{array}{l}11.461 \\
(6.184)\end{array}$ & $\begin{array}{l}0.76 \\
(0.446)\end{array}$ & $\begin{array}{l}7.159 \\
(4.560)\end{array}$ & $\begin{array}{l}8.881 \\
(7.262)\end{array}$ & $\begin{array}{l}1.08 \\
(0.281)\end{array}$ \\
\hline Nothing & 0 & 188 & & $\begin{array}{l}12.564 \\
(1.681)\end{array}$ & & & $\begin{array}{l}11.340 \\
(6.098)\end{array}$ & & & $\begin{array}{l}8.671 \\
(7.002)\end{array}$ & \\
\hline No answer & 1 & 187 & 14.00 & $\begin{array}{l}12.556 \\
(1.682)\end{array}$ & $\begin{array}{l}0.86 \\
(0.393)\end{array}$ & 9.000 & $\begin{array}{l}11.353 \\
(6.112)\end{array}$ & $\begin{array}{l}0.38 \\
(0.701)\end{array}$ & $\begin{array}{l}5.000 \\
(1.414)\end{array}$ & $\begin{array}{l}8.712 \\
(7.030)\end{array}$ & $\begin{array}{l}0.75 \\
(0.457)\end{array}$ \\
\hline Miscellaneous & 26 & 162 & $\begin{array}{l}12.654 \\
(1.700)\end{array}$ & $\begin{array}{l}12.549 \\
(1.683)\end{array}$ & $\begin{array}{l}0.29 \\
(0.769)\end{array}$ & $\begin{array}{l}11.192 \\
(6.812)\end{array}$ & $\begin{array}{l}11.364 \\
(5.999)\end{array}$ & $\begin{array}{l}0.13 \\
(0.894)\end{array}$ & $\begin{array}{l}9.900 \\
(9.259)\end{array}$ & $\begin{array}{l}8.474 \\
(6.587)\end{array}$ & $\begin{array}{l}0.95 \\
(0.346)\end{array}$ \\
\hline
\end{tabular}

Control beliefs elicited in response to question about what the participants thought would make it easy for them to drink $10.5 / 7$ units of alcohol that evening. 
Table six

Differences in PBC, intentions and behaviour, according to presence or absence of salient negative control beliefs

\begin{tabular}{|c|c|c|c|c|c|c|c|c|c|c|c|}
\hline Category & Yes & No & $\begin{array}{l}\text { PBC } \\
\text { Mean (SD) } \\
\text { yes }\end{array}$ & $\begin{array}{l}\text { Mean (SD) } \\
\text { no }\end{array}$ & Significance & $\begin{array}{l}\text { Intention } \\
\text { Mean (SD) } \\
\text { yes }\end{array}$ & $\begin{array}{l}\text { Mean (SD) } \\
\text { no }\end{array}$ & Significance & $\begin{array}{l}\text { Behaviour } \\
\text { Mean (SD) } \\
\text { yes }\end{array}$ & $\begin{array}{l}\text { Mean (SD) } \\
\text { no }\end{array}$ & Significance \\
\hline Lack of money & 107 & 81 & $\begin{array}{l}12.776 \\
(1.341)\end{array}$ & $\begin{array}{l}12.284 \\
(2.020)\end{array}$ & $\begin{array}{l}2.00 \\
(\mathbf{0 . 0 4 7})\end{array}$ & $\begin{array}{l}11.804 \\
(6.298)\end{array}$ & $\begin{array}{l}10.728 \\
(5.805)\end{array}$ & $\begin{array}{l}1.20 \\
(0.232)\end{array}$ & $\begin{array}{l}8.652 \\
(7.342)\end{array}$ & $\begin{array}{l}8.696 \\
(6.584)\end{array}$ & $\begin{array}{l}0.04 \\
(0.967)\end{array}$ \\
\hline Illness & 59 & 129 & $\begin{array}{l}12.627 \\
(1.376)\end{array}$ & $\begin{array}{l}12.533 \\
(1.807)\end{array}$ & $\begin{array}{l}0.35 \\
(0.728)\end{array}$ & $\begin{array}{l}12.948 \\
(6.160)\end{array}$ & $\begin{array}{l}10.623 \\
(5.955)\end{array}$ & $\begin{array}{l}2.45 \\
(\mathbf{0 . 0 1 5})\end{array}$ & $\begin{array}{l}10.421 \\
(7.655)\end{array}$ & $\begin{array}{l}7.867 \\
(6.558)\end{array}$ & $\begin{array}{l}2.31 \\
(\mathbf{0 . 0 2 2})\end{array}$ \\
\hline Commitments & 51 & 137 & $\begin{array}{l}12.647 \\
(1.339)\end{array}$ & $\begin{array}{l}12.600 \\
(1.795)\end{array}$ & $\begin{array}{l}0.41 \\
(0.680)\end{array}$ & $\begin{array}{l}10.510 \\
(5.658)\end{array}$ & $\begin{array}{l}11.650 \\
(6.246)\end{array}$ & $\begin{array}{l}1.14 \\
(0.256)\end{array}$ & $\begin{array}{l}8.392 \\
(6.782)\end{array}$ & $\begin{array}{l}8.798 \\
(7.106)\end{array}$ & $\begin{array}{l}0.39 \\
(0.695)\end{array}$ \\
\hline Being sensible & 24 & 164 & $\begin{array}{l}12.333 \\
(1.949)\end{array}$ & $\begin{array}{l}12.615 \\
(1.642)\end{array}$ & $\begin{array}{l}0.72 \\
(0.473)\end{array}$ & $\begin{array}{l}9.875 \\
(6.124)\end{array}$ & $\begin{array}{l}11.555 \\
(6.084)\end{array}$ & $\begin{array}{l}1.26 \\
(0.208)\end{array}$ & $\begin{array}{l}6.792 \\
(4.868)\end{array}$ & $\begin{array}{l}8.959 \\
(7.243)\end{array}$ & $\begin{array}{l}1.42 \\
(0.159)\end{array}$ \\
\hline $\begin{array}{l}\text { Poor } \\
\text { environment }\end{array}$ & 22 & 166 & $\begin{array}{l}12.046 \\
(1.704)\end{array}$ & $\begin{array}{l}12.633 \\
(1.671)\end{array}$ & $\begin{array}{l}1.55 \\
(0.124)\end{array}$ & $\begin{array}{l}11.048 \\
(6.749)\end{array}$ & $\begin{array}{l}11.377 \\
(6.033)\end{array}$ & $\begin{array}{l}0.23 \\
(0.816)\end{array}$ & $\begin{array}{l}8.500 \\
(6.850)\end{array}$ & $\begin{array}{l}8.693 \\
(7.042)\end{array}$ & $\begin{array}{l}0.12 \\
(0.908)\end{array}$ \\
\hline Unavailability & 18 & 170 & $\begin{array}{l}12.667 \\
(1.782)\end{array}$ & $\begin{array}{l}12.553 \\
(1.675)\end{array}$ & $\begin{array}{l}0.27 \\
(0.786)\end{array}$ & $\begin{array}{l}11.556 \\
(6.653)\end{array}$ & $\begin{array}{l}11.318 \\
(6.057)\end{array}$ & $\begin{array}{l}0.16 \\
(0.875)\end{array}$ & $\begin{array}{l}9.941 \\
(7.222)\end{array}$ & $\begin{array}{l}8.540 \\
(6.989)\end{array}$ & $\begin{array}{l}0.79 \\
(0.434)\end{array}$ \\
\hline Around family & 8 & 180 & $\begin{array}{l}11.750 \\
(2.121)\end{array}$ & $\begin{array}{l}12.598 \\
(1.657)\end{array}$ & $\begin{array}{l}1.40 \\
(0.162)\end{array}$ & $\begin{array}{l}8.750 \\
(6.251)\end{array}$ & $\begin{array}{l}11.456 \\
(6.084)\end{array}$ & $\begin{array}{l}1.23 \\
(0.220)\end{array}$ & $\begin{array}{l}5.813 \\
(3.683) \\
\end{array}$ & $\begin{array}{l}8.804 \\
(7.097)\end{array}$ & $\begin{array}{l}1.18 \\
(0.239)\end{array}$ \\
\hline Nothing & 6 & 182 & $\begin{array}{l}11.000 \\
(4.147)\end{array}$ & $\begin{array}{l}12.615 \\
(1.536)\end{array}$ & $\begin{array}{l}2.34 \\
(\mathbf{0 . 0 2 0})\end{array}$ & $\begin{array}{l}15.167 \\
(5.811)\end{array}$ & $\begin{array}{l}11.214 \\
(6.082)\end{array}$ & $\begin{array}{l}1.57 \\
(0.119)\end{array}$ & $\begin{array}{l}9.000 \\
(6.928)\end{array}$ & $\begin{array}{l}8.662 \\
(7.024)\end{array}$ & $\begin{array}{l}0.11 \\
(0.916)\end{array}$ \\
\hline No answer & 4 & 184 & $\begin{array}{l}13.750 \\
(0.500)\end{array}$ & $\begin{array}{l}12.538 \\
(1.688)\end{array}$ & $\begin{array}{l}1.43 \\
(0.154)\end{array}$ & $\begin{array}{l}8.250 \\
(4.992)\end{array}$ & $\begin{array}{l}11.408 \\
(6.114)\end{array}$ & $\begin{array}{l}1.03 \\
(0.307)\end{array}$ & $\begin{array}{l}6.250 \\
(6.344)\end{array}$ & $\begin{array}{l}8.726 \\
(7.023)\end{array}$ & $\begin{array}{l}0.70 \\
(0.486)\end{array}$ \\
\hline Miscellaneous & 23 & 165 & $\begin{array}{l}12.044 \\
(1.591)\end{array}$ & $\begin{array}{l}12.636 \\
(1.693)\end{array}$ & $\begin{array}{l}1.59 \\
(0.113)\end{array}$ & $\begin{array}{l}10.375 \\
(6.163)\end{array}$ & $\begin{array}{l}11.482 \\
(6.095)\end{array}$ & $\begin{array}{l}0.83 \\
(0.408)\end{array}$ & $\begin{array}{l}8.546 \\
(8.883)\end{array}$ & $\begin{array}{l}8.689 \\
(6.736)\end{array}$ & $\begin{array}{l}0.09 \\
(0.929)\end{array}$ \\
\hline
\end{tabular}

Control beliefs elicited in response to question about what the participants thought would make it difficult for them to drink $10.5 / 7$ units of alcohol that evening. 
Table seven

Predicting intentions to binge drink with beliefs as independent variables: linear regression analysis

\begin{tabular}{lll}
\hline Beliefs & Beta coefficients & p-values \\
\hline BB+ Fun & 0.127 & 0.097 \\
BB+ Sociable & 0.106 & 0.169 \\
BB+ Getting drunk & 0.131 & 0.066 \\
BB- Money & -0.138 & 0.050 \\
NB+ Friends & 0.171 & 0.025 \\
NB- Family & 0.103 & 0.174 \\
CB- Illness & 0.053 & 0.454 \\
\hline Adjusted $\mathrm{R}^{2}=0.11(\mathrm{~F}=4.4, \mathrm{df}=7,180, \mathrm{p}<0.001)$. &
\end{tabular}


Table eight

Predicting alcohol consumption at end of evening with beliefs as independent variables: linear regression analysis

\begin{tabular}{lll}
\hline Beliefs & Beta coefficients & $\mathrm{p}$-values \\
\hline BB+ Relaxation & -0.073 & 0.298 \\
BB+ Getting drunk & 0.179 & 0.010 \\
NB+ Teams & 0.202 & 0.005 \\
NB- Role models & 0.078 & 0.272 \\
CB+ Environment & 0.143 & 0.040 \\
CB+ Celebration & 0.171 & 0.014 \\
CB+ Drinking patterns & 0.147 & 0.038 \\
CB- Money & 0.121 & 0.086 \\
\hline
\end{tabular}

Adjusted $\mathrm{R}^{2}=0.18(\mathrm{~F}=5.9, \mathrm{df}=8,1172, \mathrm{p}<0.001)$. 